\title{
Cytology of basidiospore germination, penetration, and early colonization of Phaseolus vulgaris by Uromyces appendiculatus var. appendiculatus
}

\author{
R. E. Gold and K. Mendgen ${ }^{1}$ \\ Lehrstuhl für Phytopathologie, Fakultät für Biologie, Universität Konstanz, D-7750 Konstanz, Federal Republic of Germany
}

Received August 3, 1983

GOLD, R. E., and K. MENDGEN. 1984. Cytology of basidiospore germination, penetration, and early colonization of Phaseolus vulgaris by Uromyces appendiculatus var. appendiculatus. Can. J. Bot. 62: 1989-2002.

Cytological studies were done on a compatible interaction between Phaseolus vulgaris and Uromyces appendiculatus var. appendiculatus. The cytoplasm of germinated basidiospores contained numerous microbodies in close association with lipid bodies, vacuoles, and endoplasmic reticulum. A single, polar germ tube commonly developed from a germinating basidiospore. The germ tubes tended to grow toward or along the junction lines between host cpidermal cells. Appressorium formation in ca. $75 \%$ of all observations occurred less than $3.5 \mu \mathrm{m}$ away from the lines of juncture. A mucilaginous exudate was associated with germ tubes and appressoria along areas of contact between host and fungus. Epidermal wall papillae were often observed beneath basidiospores and appressoria but did not restrict entrance of the fungus. The fungus directly penetrated the epidermal cell and invaginated the host plasma membrane. The apex of the penetration peg expanded to form an ovate intraepidermal vesicle. Electron-opaque material occluded the penetration pore after migration of the usually binucleate protoplast into the vesicle. The intraepidermal vesicle developed apically and formed a multicellular primary hypha that initially was multinucleate and later became uninucleate or binucleate. The primary hypha then grew into adjacent epidermal cells, subtending palisade parenchyma cells and underlying intercellular spaces.

GOLD, R. E., et K. MENDGEN. 1984. Cytology of basidiospore germination, penetration, and carly colonization of Phaseolus vulgaris by Uromyces appendiculatus var. appendiculatus. Can. J. Bot. 62: 1989-2002.

Des études cytologiques ont été effectuées sur une interaction compatible entre Phaseolus vulgaris et Uromyces appendiculatus var. appendiculatus. Le cytoplasme des basidiospores germées contient de nombreux microgranules étroitement associés à des corps lipidiques, des vacuoles et du réticulum endoplasmique. Généralement, un seul hyphe germinatif polaire se développe d'une spore en germination. Les tubes germinatifs ont tendance à croître vers, ou le long des lignes de jonction entre les cellules épidermiques de l'höte. La formation d'appressorium dans ca. $75 \%$ de toutes les observations ont lieu à moins de $3.5 \mu \mathrm{m}$ des lignes de jonction. Un exsudat mucilagineux est associé à l'hyphe germinatif et aux appressoriums le long des surfaces de contact entre l'hôte et le champignon. Les papilles des parois épidermiques s'observent souvent sous les basidiospores et les appressoriums mais n'empêchent pas l'entrée du champignon. Le champignon pénètre directement la paroi épidermique et invagine la plasmalemme de l'hôte. L'apex de l'hyphe de pénétration se gonfle pour former une vésicule intraépidermique ovoïde. Un matériel opaque aux électrons obstrue le pore de pénétration après la migration du protoplaste usuellement binucléé dans la vésicule. La vésicule intraépidermique se développe de façon apicale et forme un hyphe multicellulaire primaire qui est multinucléé au départ et plus tard devient uninuclée ou binucléé. L’hyphe primaire se développe alors dans les cellules épidermiques adjacentes soutendant les cellules du parenchyme palissadique et tapissant les espaces intercellulaires.

[Traduit par le journal]

\section{Introduction}

Early studies of host penetration by rust basidiospore germlings were done by DeBary (1863), Reess (1870), Ráthay (1881), Ward (1888), Fischer (1898), Eriksson (1911), Robinson (1913), and Waterhouse (1921). Ruth Allen later confirmed and expanded these initial studies with detailed descriptions and illustrations of basidiospore-derived rust infections (1930, 1932a, 1932 b, 1934, 1935). Parallel to Allen's classic cytological investigations were reports on the nature of resistance and varietal susceptibility of barberry and apple to Puccinia graminis Pers. and Gymnosporangium juniperivirginianae Schw., respectively (Reed and Crabill 1915; Melhus et al. 1920; Melander and Craigie 1927; Cotter 1932; Nusbaum 1935).

Host penetration in basidiospore-derived infections is indirectly through stomata (e.g., DeBary 1863; Patton and Johnson 1970 ) or, more commonly, directly through the epidermis (e.g., Allen 1935; Miller et al. 1980). A few reports of direct penetration by infection hyphae arising from the metabasidium have also appeared (e.g., Sato et al. 1980; Kaneko and Hiratsuka 1981).

To our knowledge, all previous studies on the penetration and infection of bean by Uromyces appendiculatus (Pers.)

'Author to whom reprint requests should be addressed
Unger var. appendiculatus ${ }^{2}$ have involved urediniospores (DeBary 1863; Hardwick et al. 1971; Mendgen 1978; Pring 1980). Although Andrus (1931) carried out experiments on the sexual stage of the bean rust fungus, he gave no information on basidiospore-derived penetration and infection. The purpose of the present study was to characterize basidiospore germination, penetration, and early colonization of bean by $U$. appendiculatus var. appendiculatus. Events up to $72 \mathrm{~h}$ postinoculation (hpi) were studied on a susceptible leaf, using light and electron microscopy.

\section{Materials and methods}

\section{Plant material and inoculation}

Uromyces appendiculatus var. appendiculatus was cultured in the greenhouse on susceptible garden bean (Phaseolus vulgaris L. cv. Favorit). Teliospores were produced, stored, and induced to germinate according to methods outlined previously (Gold 1983; Gold and Mendgen 1983a).

\section{Scanning electron microscopy (SEM)}

Teliospores of the bean rust isolate SWBR, which had been stored

\footnotetext{
${ }^{2}$ Synonyms: Uromyces phaseoli (Pers.) Wint. and Uromyces phaseoli (Pers.) Wint. var. typica Arth. See Boerema and Verhoeven (1979) and Cummins (1978) for an accurate nomenclatural account of these and related species.
} 
at $4^{\circ} \mathrm{C}$ for ca. 36 months, were incubated on $2 \%$ agar at $18^{\circ} \mathrm{C}$ under $1000 \mathrm{~lx}(16 \mathrm{~h} /$ day $)$. During the dark phase $(2200-0600)$ between the 4 th and 5 th day, teliospores were suspended over the upper surface of a primary leaf from a 14-day-old susceptible bean plant (cv. Favorit). After this inoculation period, the spores were removed and the plant was further incubated at $100 \%$ relative humidity in the dark. For SEM, leaf pieces were removed from the leaf with a $6-\mathrm{mm}$ cork borer at 6 , $12,18,24$, and $36 \mathrm{~h}$ after the period of maximum basidiospore release (ca. 0500). The tissue was fixed immediately after excision in $3 \%$

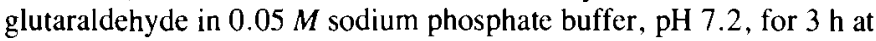
$20^{\circ} \mathrm{C}$. After fixation, the specimens were washed in buffer, dehydrated in a graded ethanol series, and dried in a Balzers critical-point dryer $\left(\mathrm{CO}_{2}\right)$. The dried specimens were coated with gold in a watercooled Balzers sputter coater and examined with either a Hitachi \$700 or Cambridge 600 scanning electron microscope operated at $15 \mathrm{kV}$.

Light and transmission electron microscopy (LM and TEM)

Teliospores were incubated on agar and suspended over a primary leaf as described above, but samples were taken at $6,12,18,24,30$, 36. 48. and $60 \mathrm{hpi}$. The samples were fixed in glutaraldehyde as described above and postfixed for $2 \mathrm{~h}$ at $4^{\circ} \mathrm{C}$ in buffered $2 \% \mathrm{OsO}_{4}$. The tissue was then washed in buffer and distilled water and dehydrated in a graded ethanol series. At the $70 \%$ ethanol stage the tissue was stained for $4 \mathrm{~h}$ in a $2 \%$ solution of uranyl acetate in $70 \%$ ethanol. Specimens were infiltrated with Spurr's resin, cured $8 \mathrm{~h}$ at $70^{\circ} \mathrm{C}$, and sectioned with either a glass or diamond knife. Serial sections were routinely cut at right angles to the lamina, mounted on Pioloformcoated, carbon-reinforced, $1 \times 2 \mathrm{~mm}$ slot copper grids, and poststained with lead citrate. Sections were examined and photographed in either a Zeiss EM 10B or Zeiss EM 10CR transmission electron microscope operated at $60 \mathrm{kV}$. For LM, 2- to 3- $\mu \mathrm{m}$-thick sections were cut and examined unstained with phase contrast optics with a Zeiss Neofluar $25 / 0.6$ or Zeiss Planapochromat $63 / 1.4$ oil-immersion objective.

In another basidiospore infection series, samples were taken at 1,2 , and 3 days postinoculation (dpi). Leaf pieces were fixed, cleared, and stored in a saturated aqueous solution of chloral hydrate $(2.5 \mathrm{~g} / \mathrm{mL})$ in the dark. The whole leaf samples were examined unstained with interference contrast optics with a Zeiss Planachromat $40 / 0.65$ objective.

\section{Terminology}

The terminology used in this paper generally corresponds to that suggested by Littlefield and Heath (1979) with the exception of terms applied to intracellular infection structures. Specifically, the term intracellular hypha, rather than monokaryotic haustorium, was used in the present study. This usage is justified in the Discussion. Littlefield and Heath (1979) did not comment on epidermal infection structures derived from basidiospores. The term "primary hypha," which was originally applied by Allen (1930), was retained. However, the initial vesiclelike portion of the primary hypha was designated the intraepidermal vesicle. It should be noted that the term "dikaryotic," as used by Littlefield and Heath (1979) and also here, refers to the heterodikaryotic condition (cf. Olive 1953).

\section{Results \\ Development from 0 to $72 \mathrm{~h}$ postinoculation}

Basidiospores on the upper leaf surface did not swell significantly prior to or during germ tube emergence. The cytoplasm of ungerminated and freshly germinated basidiospores usually contained two presumably haploid nuclei, vacuoles, lipid bodies, mitochondria, microbodies, vesicles, endoplasmic reticulum (ER), and ribosomes (Figs. 1,2). Microbodies were commonly closely appressed to or positioned between lipid bodies, which in turn were associated with vacuoles (Fig. 1). Other configurations were observed (Fig. 2) and in all cases ER was present and frequently situated near the side of the microbody facing away from the lipid body. Chromatin varied in appearance from dispersed to condensed in the interphase nuclei of freshly germinated basidiospores and in intracellular infection structures. During basidiospore germination, the mitochondria were often positioned in a narrow zone near the periphery of the spore (Fig. 1). The cell wall of mature basidiospores was ca. $0.12 \mu \mathrm{m}$ thick and consisted of a single wall layer covered by an outer mucilaginous exudate (Fig. 1, inset). The exudate was most evident on the side closest to the epidermis. No preformed germ pore region was found in the cell wall of basidiospores. The cell wall was often very difficult to see in TEM because of its poor staining properties.

A single, polar germ tube usually emerged from the end of the basidiospore opposite the apiculus (Figs. 3,5,6). Less frequently, the germ tubes arose laterally or bipolarly. The amount of germ tube growth on the leaf surface varied prior to appressorium formation and penetration. Whereas ca. $60 \%$ of the germ tubes differentiated an appressorium soon after emergence (Figs. 3,4), ca. 40\% delayed appressorium formation until the germ tube was as long as (Fig. 6) or several times longer than the spore itself (Fig. 5). The appressorium also varied in appearance, ranging from a distinctly thickened terminus of the germ tube (Fig. 4) to an unenlarged germ tube end (Fig. 6). The appressorium was not delimited from the germ tube by a septum.

Most germ tubes grew toward or along the junctions between epidermal cells (Fig. 6). However, some of the observed germ tubes grew randomly on the leaf surface without special orientation to the cell ridges or junctions (Fig. 5). In ca. $75 \%$ of all cases $(n=638)$ the appressoria were less than $3.5 \mu \mathrm{m}$ away from the anticlinal wall junctions of the epidermis. This distribution of appressoria was significant at $P<0.05$ using chisquare analysis.

A mucilaginous exudate was secreted by the developing basidiospore germling (Figs. 5,6). Copious depositions were characteristically produced around the appressorium (Fig. 4).

ABBrEviATIONS USED: A, apiculus; Ap, appressorium; Aw, appressorial wall; Bs, basidiospore; $c$, collar; $c h$, chloroplast; $c u$, cuticle; Cw, host cell wall; E, epidermal cell; Eh, extrahyphal membrane; Ehm, extrahyphal matrix; Ev, intraepidermal vesicle; Ew, epidermal cell wall; Fpm, fungal plasma membrane; G, germ tube; Gb, Golgi body; H, intracellular hypha; Hc, host cytoplasm; Hn, host nucleus; hnu, host nucleolus; Ipm, invaginated plasma membrane; Is, intercellular space; L, lipid body; $m$, mitochondrion; $m b$, microbody; $m s$, mucilaginous exudate; $\mathrm{N}$, fungal nucleus; $n u$, fungal nucleolus; $\mathrm{P}$, papilla; $\mathrm{Pc}$, palisade parenchyma cell; $\mathrm{Ph}$, primary hypha; $\mathrm{Pm}$, host plasma membrane; $\mathrm{Pp}$, penetration peg; $S$, septum; $S w$, basidiospore cell wall; $V$, fungal vacuole.

FIGS. 1 and 2. Transmission electron microscopy (TEM) of germinated basidiospores. Fig. 1. (6 hpi) A section through germinated basidiospore (germ tube not in plane of section). The thin, electron-lucent cell wall of the spore stains weakly compared with fungal protoplast. Note nuclei with dispersed chromatin (arrows), close spatial association of lipid bodies, vacuoles, and microbodies, and ring of mitochondria at the periphery of the spore cell wall. $\times 12800$. Inset. Higher magnification of basidiospore cell wall shown in Fig. 1 but from another section. The spore wall is covered by a fibrillar mucilaginous material. $\times 19750$. Fig. 2. (6 hpi) Part of an elliptical, germinated basidiospore (appressorium and developing intraepidermal vesicle not shown) on bean epidermis. The section shows details of the extensive smooth and rough perinuclear endoplasmic reticulum (arrows). $\times 19600$. 


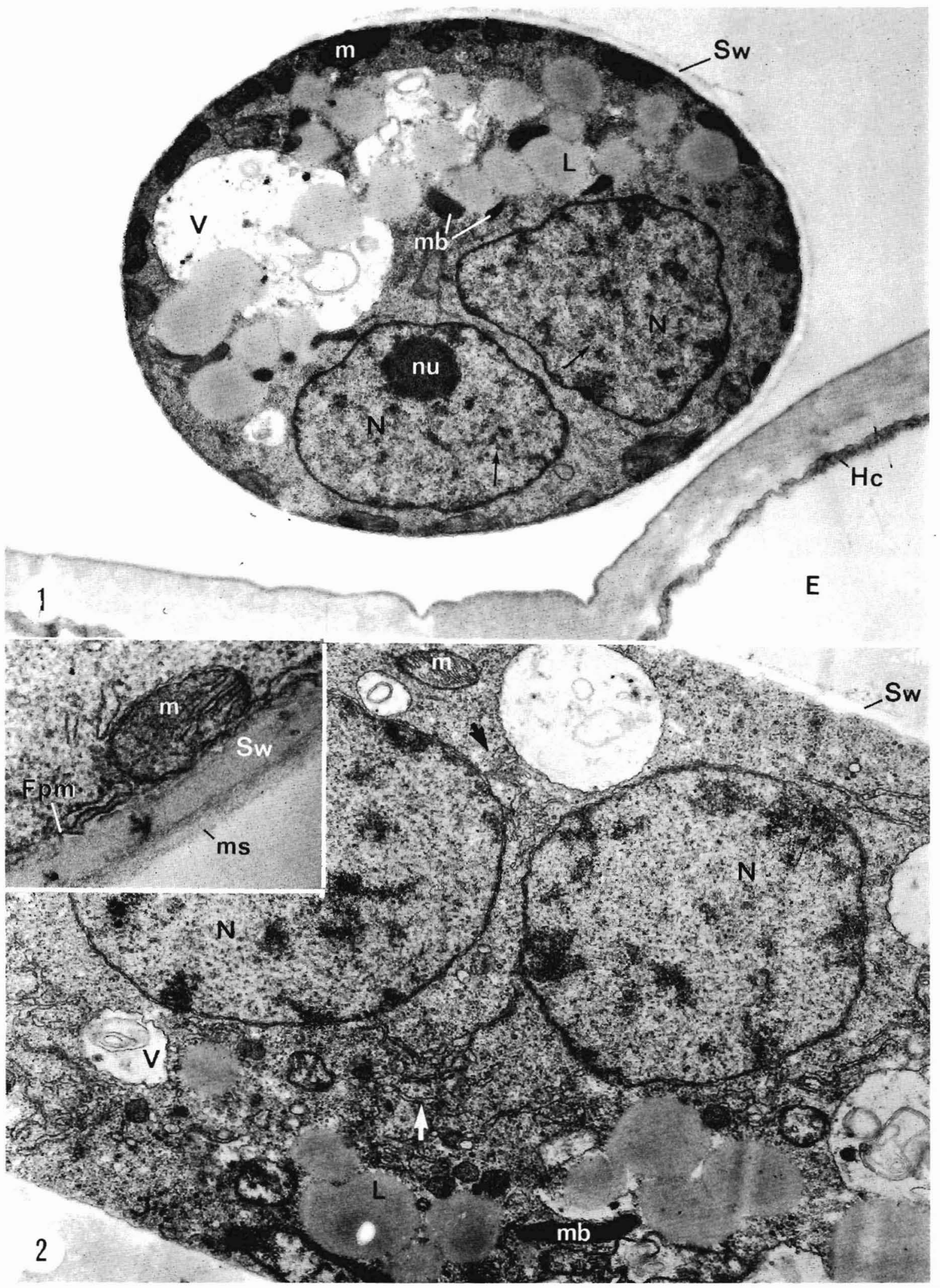




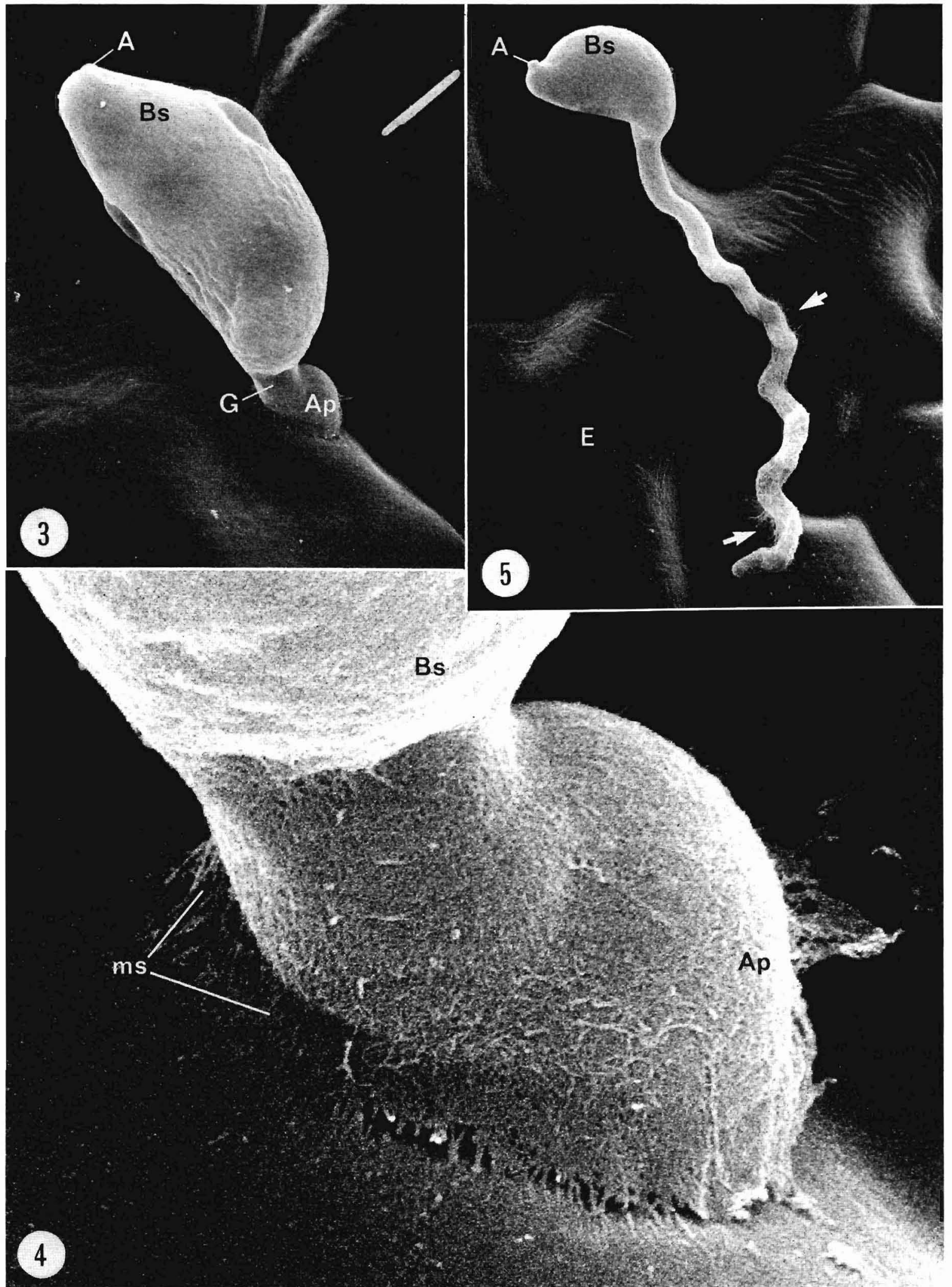

FIGS. 3-5. Scanning electron microscopy (SEM) of basidiospore germination and penetration of upper bean leaf surface. Fig. 3. (24 hpi) Germinated basidiospore produced a short germ tube and a distinct appressorium. $\times 3990$. Fig. 4. Enlargement of appressorium shown in Fig. 3. The adhesive property of the mucilaginous exudate is evident. $\times 27450$. Fig. 5 . (28 hpi) Basidiospore with long germ tube showing characteristic zig-zag growth pattern and mucilaginous exudate (arrows). The peglike apiculus is seen at the spore end opposite the germ tube. $\times 1490$. 


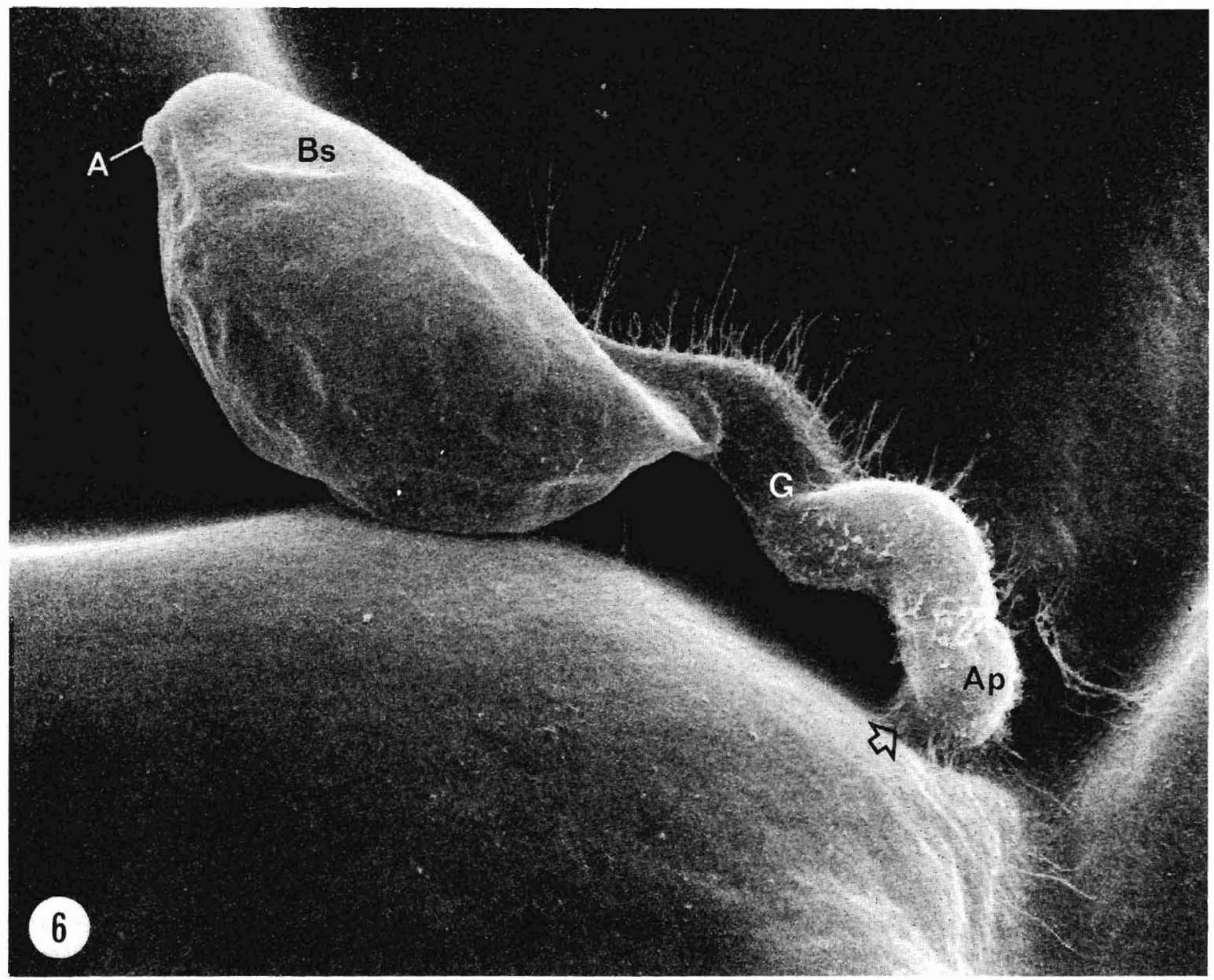

FIG. 6. SEM of basidiospore penetration of upper bean leaf surface. $(24 \mathrm{hpi})$ Direct penetration near the junction of three epidermal cells. Observe the fibrouslike material along the germ tube and increased deposition of mucilage (arrow) at the base of the appressorium. $\times 5550$.

The penetration process began with the attachment of the fungus to the host via the appressorium and its exudate (Figs. 4,6,12). The exudate extended laterally on the epidermal surface up to $2 \mu \mathrm{m}$ away from the fungal wall (Fig. 6).

Disc-shaped papillae often formed inside the outer epidermal cell wall at points directly beneath germinating basidiospores and developing appressoria (Figs. 7,11,16), but they did not prevent entry of the phase-dense penetration peg into the epidermis (Fig. 8). In cross section these wall appositions appeared granular to coarsely striated and were clearly distinguishable from the epidermal cell wall (Fig. 11).

The diameter of the penetration peg at the entrance point in the cuticle was ca. $0.4 \mu \mathrm{m}$. However, the fungus expanded immediately thereafter in the wall region to a diameter of ca. $1.3 \mu \mathrm{m}$ (Fig. 13). The wall of the penetration peg, which did not appear to be continuous with the wall of the appressorium, originated from slightly within the appressorium (Figs. 13,14). The peg penetrated the cuticle and epidermal wall and invaginated the host plasmalemma. After a short period of growth, it swelled distally to form an ovate intraepidermal vesicle (Figs. 8,9,16,26). Most of the cytoplasm and both nuclei migrated into the vesicle, leaving the basidiospore somewhat vacuolated (Figs. 9,16). After cytoplasmic and nuclear migration into the vesicle and developing primary hypha, a zone, devoid of cytoplasm and not delimited by septa, formed in the neck region between the necrotic appressorium and turgid protoplasm in the vesicle (Figs. 16,18). At this time the penetration pore was occluded with an electron-opaque material similar to that observed at the periphery of the penetration pore (Fig. 16) and in the necrotic appressorium (Fig. 18). Only direct penetration of the epidermis was observed.

After penetration, the cytoplasm of the invaded epidermal cell aggregated around the developing intraepidermal vesicle (Figs. 9,17). The epidermal cell nucleus was often closely appressed to the vesicle or apex of the primary hypha (Figs. 15,17). The binucleate condition remained stable during basidiospore germination (Figs. 1,2,7), host penetration, and development of the intraepidermal vesicle (Figs. 9,16,26). The vesicle then grew apically to initiate primary hyphal development (Figs. 10,17,26). At this time two to four nuclei were commonly observed in the young primary hypha (Fig. 10). Upon further growth and septation, a reversion to the uninucleate or binucleate condition took place.

The primary hypha increased in length, branched extensively, penetrated into neighboring epidermal cells, and soon developed into a multicellular network of hyphae in several adjoining epidermal cells (Figs. 17, 19-21,27,28). Branches of primary hyphae also grew downward into the underlying palisade parenchyma cells (Figs. 22,24,29-31) and intercellular spaces (Fig. 23). The intraepidermal vesicle became increasingly vacuolated (Figs. 10,17,20,26) and was separated from the apically growing mycelium by a septum (Figs. 17,27,28).

Septum formation typically occurred prior to transcellular 


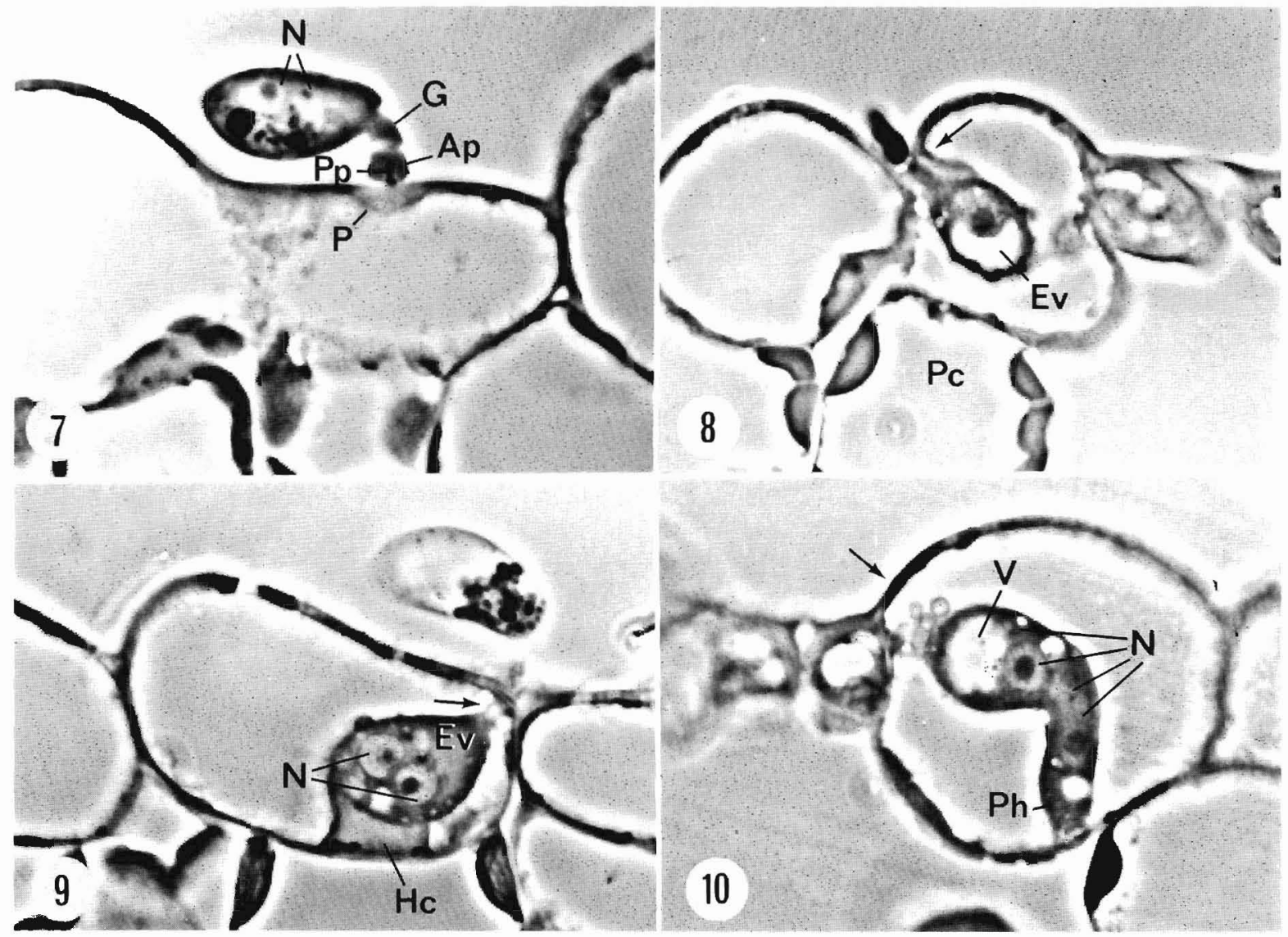

FIGS. 7-10. Light microscopy (LM) (phase contrast) of basidiospore penetration and infection of susceptible bean. Fig. 7 . (12 hpi) Initial stages of penetration. Germinated basidiospore, germ tube, and appressorium with phase-dense penetration peg. Observe papilla subtending penetration site. $\times 1430$. Fig. 8. (24 hpi) Formation of intraepidermal vesicle. Note location of penetration at the junction of two cells and a collar at the penetration site (arrow). ×1185. Fig. 9. (6 hpi) The two nuclei and cytoplasm have migrated through the narrow penetration tube (arrow) into the ovate intraepidermal vesicle. The small amount of host cytoplasm in the invaded epidermal cell is located at the distal portion of the vesicle. $\times 1500$. Fig. 10. (24 hpi) Development of the primary hypha by apical growth of the intraepidermal vesicle, the latter becoming concomitantly vacuolated. Four nuclei are present. The penetration site (not in plane of section) is indicated at arrow. $\times 1330$.

penetration into adjoining epidermal and palisade cells (Figs. 21,29 ) or exit into intercellular spaces. In general, the hypha was constricted in the transcellular penetration and exit regions, but thereafter it regained its normal diameter (Figs. 21,22,30). Host cell wall thickening sometimes accompanied the penetration and exiting processes, leaving behind collarlike remnants of the wall apposition (Figs. 21,23).

The diameter of transcellular penetration pores was variable but characteristically larger than the penetration pore into the epidermis. The invaginated plasma membrane of the epidermal cell was continuous with the native plasma membrane at points directly adjacent to the penetration site (Fig. 30). There was no evidence of host plasma membrane in the penetration pore between the epidermal and palisade cell. The invading hypha again invaginated the plasma membrane of the recipient host cell (Fig. 30). Intracellular hyphae in palisade cells were initially fingerlike, uninucleate or binucleate, usually elongated parallel to the axis of the cells, and sometimes septate (Figs. 22,24). Ultimately, they grew out into the intercellular space (Fig. 25). The apices of these hyphae were typically packed with polyribosomes and in the subapical regions numerous vesicles were intermingled with intricate ER formations, followed by a zone rich in mitochondria (Fig. 31).

\section{Chronology of infection process}

The events of basidiospore germination, penetration, and host colonization were not well synchronized with one another. In some instances an intraepidermal vesicle had formed as soon as 6 or as late as $30 \mathrm{~h}$ after inoculation. Despite this lack of synchronization, representative stages of development were identified and are chronologically summarized (cf. Fig. 32).

\begin{tabular}{cc}
\hline \hline hpi & Events \\
\hline $0-6$ & $\begin{array}{c}\text { Germination; development of germ tube and appressorium } \\
\text { Direct host penetration; formation of intraepidermal vesicle } \\
\text { and primary hypha }\end{array}$ \\
$12-24$ & $\begin{array}{c}\text { Growth and branching of primary hypha; transcellular } \\
\text { penetration into adjoining epidermal cells } \\
\text { Growth and branching of primary hypha; transcellular } \\
\text { penetration into adjoining epidermal and palisade cells; } \\
\text { exit into intercellular spaces }\end{array}$ \\
$48-72$ & $\begin{array}{c}\text { Further expansion of mycelium; four or five epidermal and } \\
\text { two or three palisade cells on the average infected; exit } \\
\text { into intercellular spaces }\end{array}$ \\
\hline
\end{tabular}

\section{Discussion}

\section{Prepenetration}

Our knowledge of the ultrastructure of basidiospores of rust fungi, as based on previous studies and the present work, can be summarized as follows. Surfaces of basidiospores are smooth to slightly roughened or reticulate (Kohno, Nishimura 

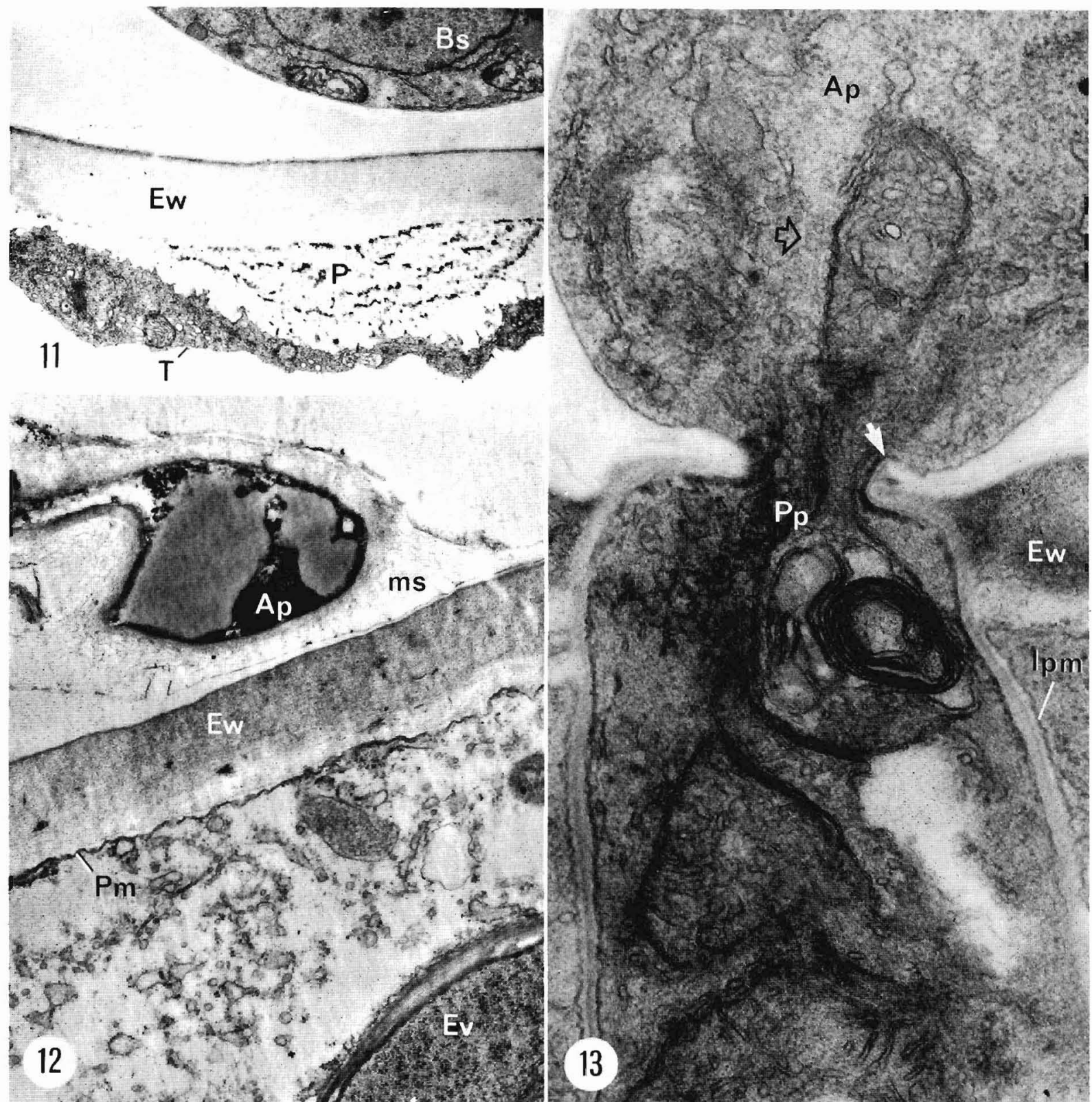

FIGS. 11-13. TEM of penetration and infection of susceptible bean by basidiospore-derived mycelium. Fig. 11. (6 hpi) A papilla with striated electron-opaque material formed against the inner side of the epidermal wall directly below a germinated basidiospore. $\times 11900$. Fig. 12. (18 hpi) A longitudinal section of a necrotic appressorium showing its attachment to the epidermal cell wall by the mucilaginous exudate. Note the fibrillar substructure of the exudate. $\times 20000$. Fig. 13. (6 hpi) Median section through a penetration site. The white arrow indicates approximately where the wall of the penetration peg begins. The wall of the penetration peg is continuous throughout the penetration pore. Microtubules are shown in the appressorium at the open arrow. $\times 40400$.

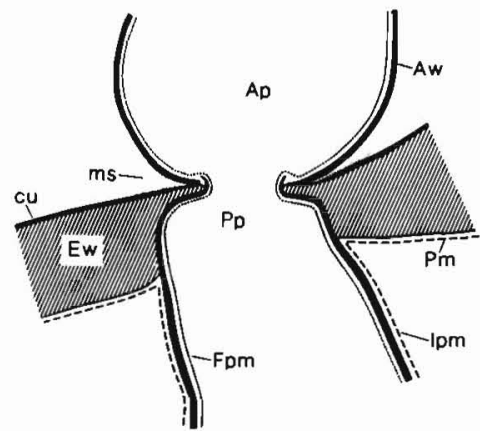

FIG. 14. Diagrammatic representation of epidermal penetration site. et al. 1977; Gold and Littlefield 1979; Gray et al. 1982; Jacobi et al. 1982; Metzler 1982). The spore wall is thin $(0.10-$ $0.25 \mu \mathrm{m}$ ) (Kohno, Nishimura et al. 1977; Mims 1977, 1981), very difficult to stain for TEM, and appears as either one (Kohno et al. 1975; Kohno, Nishimura et al. 1977; Akai et al. 1976; Mims 1977; Metzler 1982) or two layers (Mims 1977; Metzler 1982). In the bean rust fungus, basidiospore germination generally occurred apically (opposite the apiculus). However, in other species, germ tubes have been reported to form laterally (Mims 1977) or at any location on the spore (Metzler 1982; Gray et al. 1983). Preformed germ pores have not been reported.

The basidiospores of the bean rust fungus normally produced a single, unbranched germ tube; similar observations were re- 


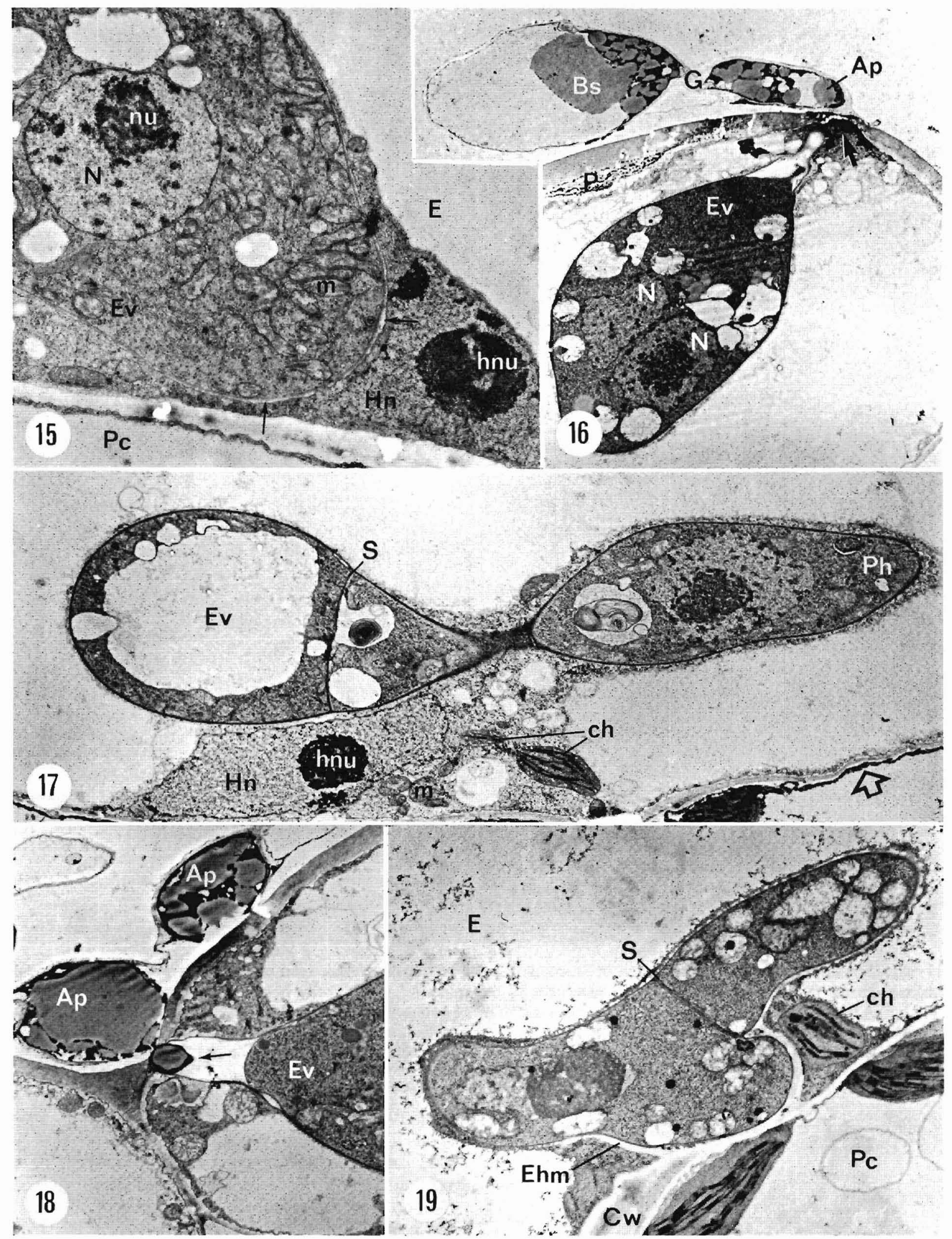




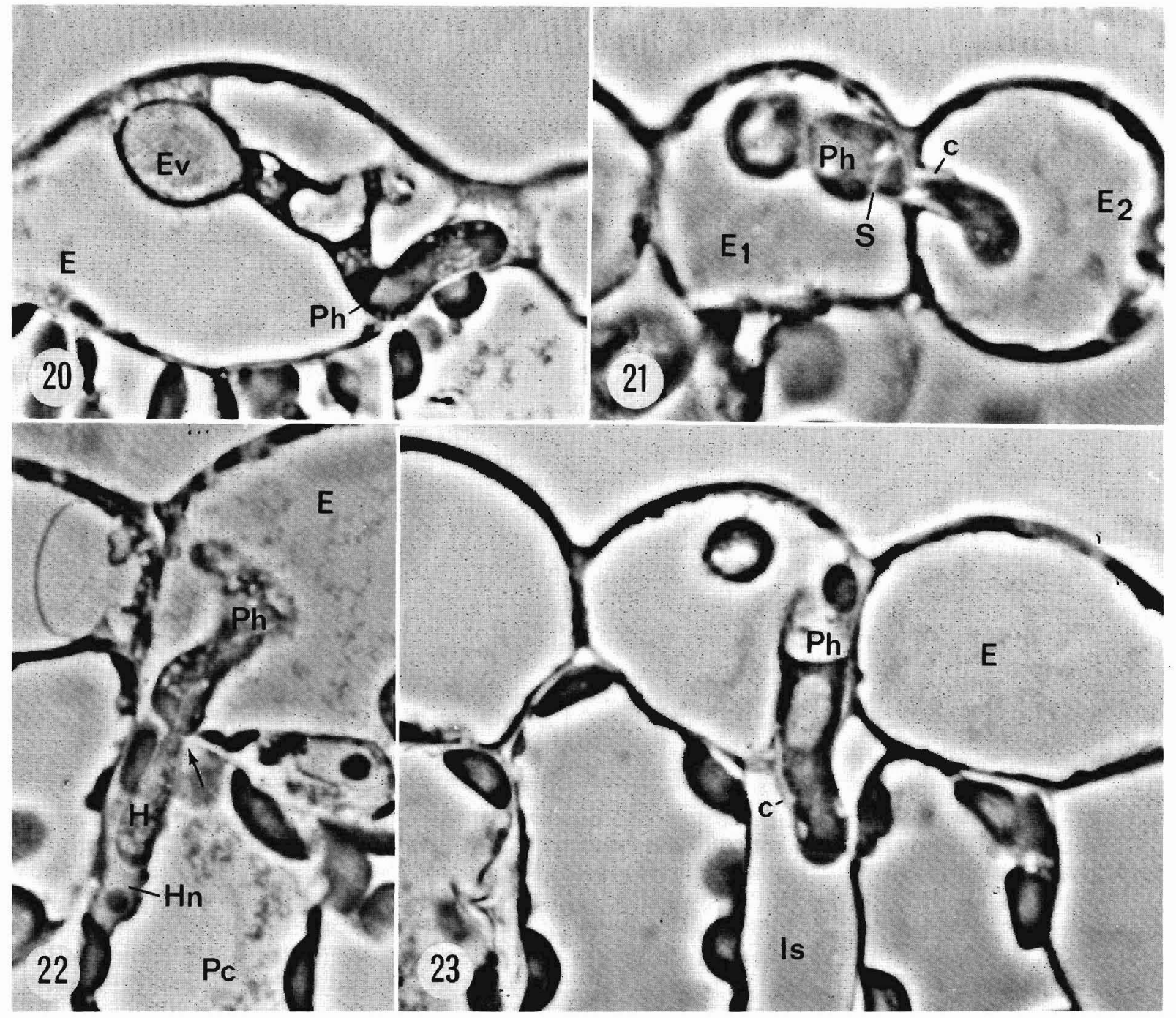

FIGs. 20-23. LM (phase contrast) of infection of susceptible bean by basidiospore-derived mycelium. Fig. 20. (48 hpi) Elongation and branching of the primary hypha is associated with vacuolation of the intraepidermal vesicle. $\times 1390$. Fig. 21 . (48 hpi) Growth of the primary hypha from the first invaded epidermal cell $\left(E_{1}\right)$ into an adjacent cell $\left(E_{2}\right)$. Note septum proximal to transcellular penetration point and the phase-lucent collarlike wall apposition of the anticlinal wall. $\times 1780$. Fig. 22 . ( $36 \mathrm{hpi}$ ) Transcellular growth of the primary hypha into a palisade cell. Penetration had occurred at the arrow. The nucleus of the palisade cell is closely associated with the apex of the intracellular hypha. $\times 1580$. Fig. 23. (48 hpi) Growth of the primary hypha into intercellular space. A thin collar (cf. Fig. 21) is present at the exit site. $\times 1690$.

ported for Gymnosporangium asiaticum Miyabe et Yamada (Kohno, Nishimura et al. 1977), Gymnosporangium fuscum DC. (Metzler 1982), and Cronartium quercuum (Berk.) Miyabe ex Shirai f. sp. fusiforme (Jacobi et al. 1982; Gray et al. 1983). Basidiospore germlings of $U$. appendiculatus var. appendiculatus showed a marked tendency to grow along epidermal cell wall junctions. This preference to follow the cleavage line is common for direct-penetrating fungi and may be induced by either contact or chemical responses by the germ tubes (Wynn and Staples 1981). The growth pattern of basidiospore germlings in other species has been reported to be random (Hansen and Patton 1977; Gray et al. 1983) or nonrandom (Jacobi et al. 1982).

Appressoria in numerous direct-penetrating fungi form preferentially near or at epidermal cell junctions (Reess 1874; Eriksson 1911; Melhus et al. 1920; Allen 1932b, 1935; Hunt

FIGS. 15-19. TEM of penetration and infection of susceptible bean by basidiospore-derived mycelium. Fig. 15. (6 hpi) Longitudinal section of an intraepidermal vesicle in close association with the epidermal cell nucleus. Numerous mitochondria are seen near the apical region (=incipient primary hypha). An electron-lucent matrix region (arrows) exists only at the distal portion of the intraepidermal vesicle. $\times 7850$. Fig. 16. (12 hpi) Penetration site showing basidiospore, germ tube, appressorium, and intraepidermal vesicle. A disk-shaped papilla is present below the basidiospore. Note electron-opaque layer (arrow) at the penetration site. $\times 3600$. Fig. 17 . (24 hpi) A vacuolated intraepidermal vesicle and portion of the newly formed primary hypha are separated by a septum. The epidermal cell nucleus, mitochondria, and two chloroplasts are seen in an aggregate of host cytoplasm below the vesicle and primary hypha. Note the prominent nucleolus of the host nucleus and the layer of electron-opaque material (arrow) inside the subtending palisade cell. $\times 4350$. Fig. $18 .(18 \mathrm{hpi})$ Two separate necrotic appressoria above penetration sites of the epidermis. The fungal protoplast in the intraepidermal vesicle is separated from the necrotic appressorium by the occluded penetration pore (arrow, cf. Fig. 16). $\times 5050$. Fig. 19. (60 hpi) Branch and septum formation prior to transcellular growth into the palisade cell. Note the conspicuous electron-lucent extrahyphal matrix around the lower branch. $\times 4950$. 


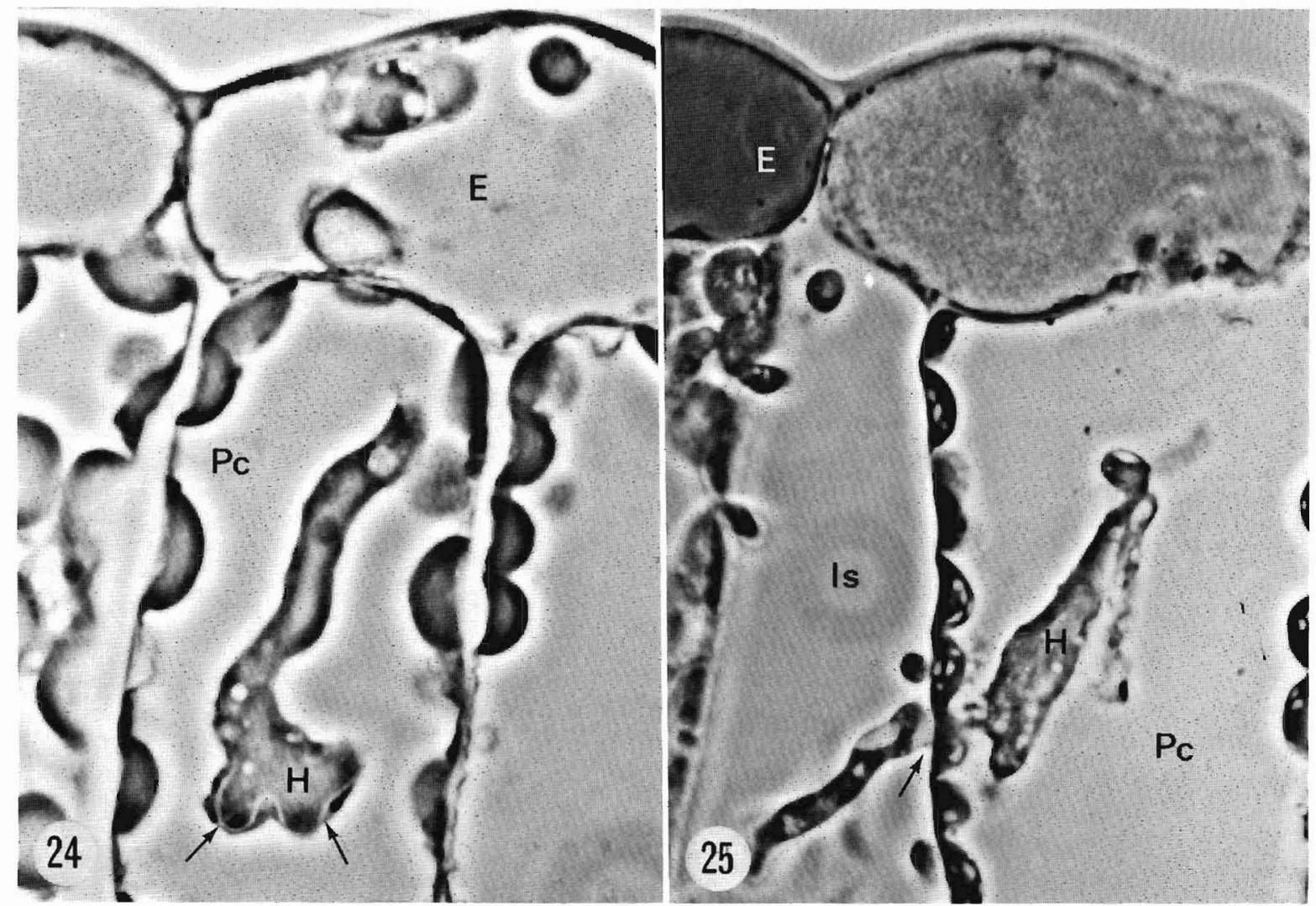

FIGS. 24 and 25. LM (phase contrast) of infection of susceptible bean by basidiospore-derived mycelium. Fig. 24 . (60 hpi) Intracellular hypha in a palisade cell. Note the light bandlike region (arrows) at the apex of the hypha. This region represents the extrahyphal matrix. $\times 1540$. Fig. 25. (ca. $72 \mathrm{hpi}$ ) Growth of an intracellular hypha from a palisade cell into the intercellular space. The exit site is shown at arrow. $\times 1140$.

1968; Bonde et al. 1976; Bonde et al. 1982; Lapp and Skoropad 1978; Gold and Littlefield 1979; Staples and Macko 1980; see Wynn and Staples 1981).

The formation of a slightly swollen, terminal appressorium, which is not delimited from the basidiospore germ tube by a septum, seems to be common to all rust species reported. A mucilaginous exudate was deposited along all areas of contact between the host epidermis and the bean rust fungus, especially at the periphery of the appressorium. This feature has been reported in numerous direct-penetrating rusts (Waterhouse 1921; Gold and Littlefield 1979; Littlefield and Heath 1979; Jacobi et al. 1982; Metzler 1982; Gray et al. 1983; see Littlefield and Heath 1979) and nonrust fungi (Mercer et al. 1975; Landes and Hoffman 1979; Rijkenberg et al. 1980). Jacobi et al. (1982), however, also showed exudate occurring at contact points between basidiospores of $C$. quercuum $\mathrm{f}$. sp. fusiforme, suggesting a nonspecific contact response. The role of fungal exudates in the penetration process appears multiple in nature: $(i)$ attachment to the plant surface and sealing up of the penetration site, (ii) protection of the appressorium against desiccation and other limiting environmental factors, and (iii) reservoir for "penetration enzymes."

\section{Penetration}

The minimum time necessary for basidiospores to penetrate and form intraepidermal vesicles was ca. $6 \mathrm{~h}$ for $U$. appendiculatus var. appendiculatus. This agrees with earlier studies on C. quercuum f. sp. fusiforme (Snow 1968), Cronartium ribicola J. C. Fisch. ex Rabenh. (Van Arsdel (1972), cited in Diner and Mott (1982)), G. juniperi-virginianae (Weimer 1917), Kuehneola japonica (Diet.) Diet. (Kohno, Ishizaki et al. 1977), and $P$. graminis (Waterhouse 1921). In contrast to teliospore germination (Gold 1983; Gold and Mendgen 1983b), light was not required for basidiospore penetration; identical infection levels were acquired when the initial $48 \mathrm{~h}$ of incubation were in either light or dark.

We found reports of direct penetration by basidiospore germlings in 18 different rust species. All, except one (C. quercuum f. sp. fusiforme) (Miller et al. 1980; Jacobi et al. 1982; Gray et al. 1983), occurred on angiosperms. On the other hand, of the five reports we found on indirect penetration, all but one species (Puccinia arenariae (Schum.) Wint.) (DeBary 1863) produced infections on gymnosperms. The epidermis of needles in Pinus spp. and, to various extents, all gymnosperms, is characterized by its heavily cutinized, thick-walled surface. The extreme rigidity of even young needles presents a tough physical barrier to basidiospores of rust fungi. Thus, basidiospores from Chrysomyxa abietis (Wallr.) Unger (Grill et al. 1978), Coleosporium spp. (Fischer 1898; Bauer 1983), and C. ribicola (Patton and Johnson 1970) appear to have adapted indirect penetration in response to the impenetrable host epidermis.

\section{Postpenetration}

The morphology and development of the epidermal infection structures in the bean rust fungus appeared similar to that described for other rusts (DeBary 1863; Allen 1930, 1932a, 1932b, 1934, 1935; Kohno, Ishizaki et al. 1977; Metzler 1982; Gray et al. 1983). In contrast to previous reports, the terms intraepidermal vesicle and primary hypha were used in the present study to emphasize the distinct morphology of those structures. 


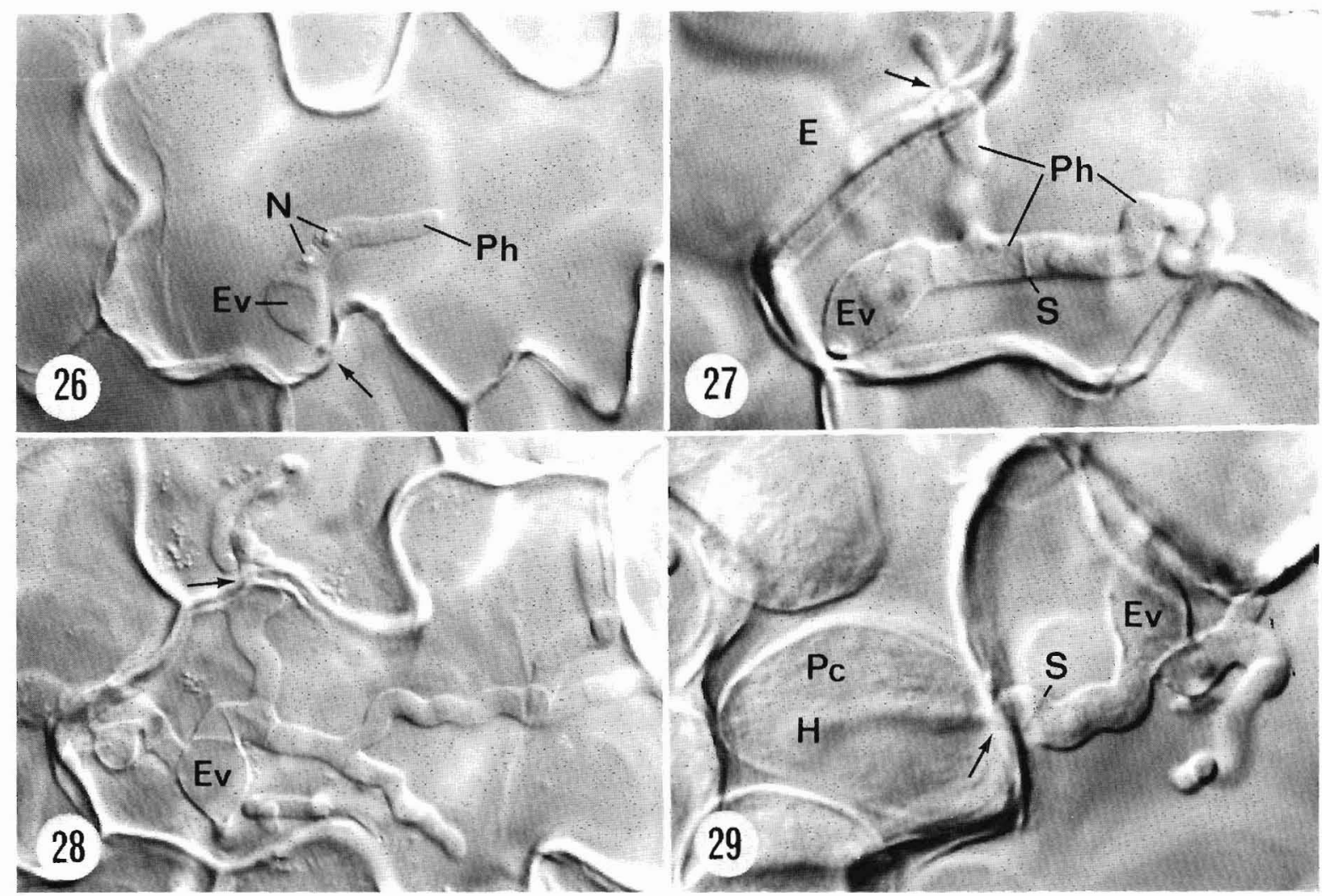

FIGS. 26-29. LM (differential interference contrast) of basidiospore-derived infection in fixed and cleared whole leaf samples. Fig. 26. (12 hpi) Ovate intraepidermal vesicle and elongating primary hypha with two nuclei. The point of penetration into the epidermis near the cell junction is shown (arrow). $\times 840$. Fig. 27 . (2 dpi) A septum separates the developing primary hypha from the intraepidermal vesicle. A branch of the primary hypha has entered an adjacent epidermal cell at arrow. $\times 1060$. Fig. 28 . (4 dpi) The multicellular primary hypha has become highly branched. A transcellular penetration site is shown at arrow. $\times 810$. Fig. 29. ( 2 dpi) Transcellular growth (arrow) of the primary hypha into subtending palisade cell. Note septum near the penetration site. $\times 1070$.

Littlefield and Heath (1979) and Harder and Chong (1984) recently reviewed the terminology for the subepidermal intracellular structures derived from basidiospores. In both reviews the authors proposed that the term "monokaryotic haustorium" be generally used unless it could be shown that the intracellular structures do not remain terminal in the invaded cell. In this case, they concluded that the term intracellular hypha would be more appropriate. Unfortunately, this descriptive approach is not readily applicable to the bean rust fungus or other rust species because of the two basic problems. (i) Basidiospores and subsequent mycelia are not always monokaryotic. They may contain more than one nucleus per cell (Allen 1934; Rijkenberg and Truter 1973; Robb et al. 1975; Kohno, Ishizaki et al. 1976, 1977; Kohno, Nishimura et al. 1977; Borland and Mims 1980; Metzler 1982). (ii) The terminal or nonterminal morphology of intracellular structures derived from basidiospores is influenced by spatial and temporal factors; either morphological type may be encountered depending on where (e.g., epidermis or spongy parenchyma) and when (e.g., $24 \mathrm{hpi}$ or $10 \mathrm{dpi}$ ) examinations are made (cf. Gold and Mendgen 1984). In view of these difficulties and hyphalike nature of the intracellular structures, the term intracellular hypha was chosen. Another problem with the monokaryotic versus dikaryotic terminology is that "dikaryotic" haustoria of at least some Puccinia spp. are in fact mononucleate (Harder and Chong 1984).

Based on previous light and electron microscopic studies and the results presented here, the development of basidiospore- derived infection structures subsequent to direct penetration of the epidermis may be summarized as follows. An ovate to elliptical intraepidermal vesicle forms immediately after penetration of the epidermal cell wall. A branched, multicellular, uninucleate or multinucleate primary hypha then develops in the invaded epidermal cell. Primary hyphae grow into either adjacent epidermal cells, subtending parenchyma palisade cells, or underlying intercellular spaces. Primary hyphae of the bean rust fungus generally grew through a palisade cell before exiting into the intercellular space. Thereafter, its development was characterized by extensive intercellular growth and formation of terminal intracellular hyphae, similar to the pattern of development in G. juniperi-virginianae (Nusbaum 1935) and $P$. graminis (Allen 1930).

A reversion in hyphal cells from binucleate or multinucleate to uninucleate occurred. Termed dediploidization (Buller 1950) or dedikaryotization (Littlefield and Heath 1979), this has been observed in several rusts (Eriksson 1911; Allen 1930, 1932a, 1932b, 1935; Ashworth 1935; Lamb 1935; Nusbaum 1935; Metzler 1980). In contrast, Lindfors (1924), Thirumalachar (1939), and Kohno, Ishizaki et al. (1977) showed that the binucleate condition remains stable after basidiospore germination, penetration, and host colonization. Allen (1934) reported an increase in the number of nuclei from one in the intraepidermal vesicle and primary hypha to many in the intercellular and intracellular hyphae.

The bean rust fungus readily grew through contiguous cell walls between epidermal cells and between epidermal and pal- 

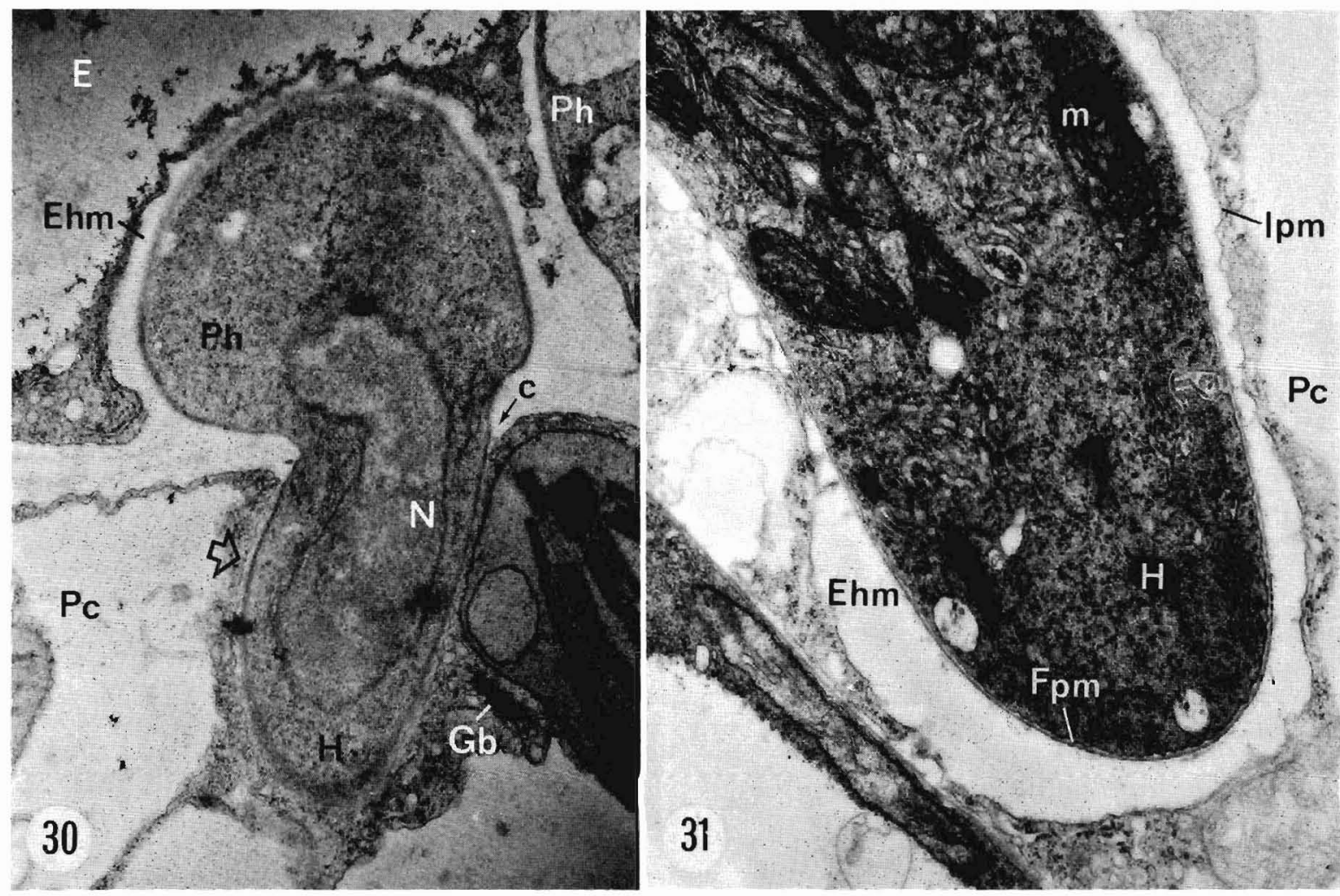

FIGS. 30 and 31. TEM of basidiospore-derived infection of susceptible bean. Fig. 30. (60 hpi) Longitudinal section of a transcellular penetration site. The primary hypha has grown through the contiguous cell walls of the epidermis and palisade cell to form an intracellular hypha in the latter. The primary hypha is surrounded by a conspicuous electron-lucent extrahyphal matrix bounded by the invaginated plasma membrane of the epidermal cell. In contrast, the invaginated plasma membrane of the palisade cell has receded only slightly from the fungal wall of the intracellular hypha at its base (arrow). Note fungal nucleus at the penetration site. $\times 14000$. Fig. 31 . (48 hpi) Longitudinal section through the tip of a young intracellular hypha near the lower periclinal wall of the palisade cell. An extensive electron-lucent extrahyphal matrix surrounds the apical portion of the hypha (cf. Fig. 30). The plasma membrane of the hypha and the invaginated host plasma membrane are undulate. Note group of mitochondria in subapical region of the hypha. $\times 18200$.

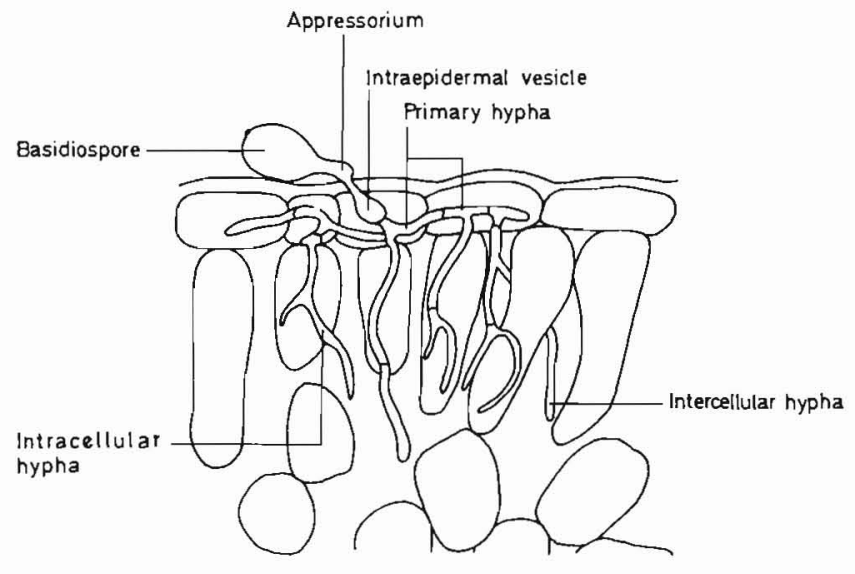

FIG. 32. Diagrammatic representation of basidiospore-derived penetration and infection ( $0-72 \mathrm{hpi})$ of bean by $U$. appendiculatus var. appendiculatus.

isade parenchyma cells. In the present study the invaginated host membrane appeared continuous with the noninvaginated plasma membrane at transcellular penetration sites (Fig. 30). This type of membrane fusion has been previously reported (Metzler 1980; Gray et al. 1983). The importance of intracellular hyphae in the uptake of host nutrients and possibly in mediating host-pathogen compatibility is an important question to be addressed in future studies.

\section{Acknowledgements}

We thank Dr. M. Müller (ETH, Zürich) for use of the Hitachi scanning electron microscope and Professor L. J. Littlefield and Ms. B. E. Hazen for their helpful comments on earlier drafts of this paper. We also extend our thanks to Mrs. E. Dressler for photographic assistance and Mr. F. Meinhardt for preparation of Fig. 32. R.E.G. gratefully acknowledges Mr. A. C. Töpfer for providing an Alexander von Humboldt student fellowship during the initial stages of this work.

AKal, S., M. FuKuTOMi, H. KUnOH, and M. Shiraishi. 1976. Fine structure of the spore wall and germ tube change during germination. In The fungal spore: form and function. Edited by D. J. Weber and W. M. Hess. John Wiley and Sons, New York. pp. $355-411$

ALLEN, R. F. 1930. A cytological study of heterothallism in Puccinia graminis. J. Agric. Res. 40: 585-614.

1932a. A cytological study of heterothallism in Puccinia triticini. J. Agric. Res. 44: 733-754.

1932b. A cytological study of heterothallism in Puccinia coronata. J. Agric. Res. 45: 513-541.

_ 1934. A cytological study of heterothallism in flax rust. J. Agric. Res. 49: 765-791.

1935. A cytological study of Puccinia malvacearum from the sporidium to the teliospore. J. Agric. Res. 51: $801-818$. 
ANDRUS, C. F. 1931. The mechanism of sex in Uromyces appendiculatus and $U$. vignae. J. Agric. Res. 42: 559-587.

AsHWORTH, D. 1935. An experimental and cytological study of the life history of Endophyllum sempervivi. Trans. Br. Mycol. Soc. 19: $240-258$.

BAUER, R. 1983. Experimentell-ontogenetische und karyologische Untersuchungen an Uredinales. Doctoral dissertation, Universität Tübingen, Tübingen, Federal Republic of Germany.

Boerema, G. H., and A. A. Verhoeven. 1979. Check-list for scientific names of common parasitic fungi. Series $2 c$. Fungi on field crops: pulse (legumes) and forage crops (herbage legumes). Neth. J. Plant Pathol. 85: 151-185.

BONDE, M. R., K. R. BRomfield, and J. S. MELChing. 1982. Morphological development of Physopella zeae on corn. Phytopathology, 72: 1489-1491.

Bonde, M. R., J. S. Melching, and K. R. Bromfield. 1976. Histology of the suscept - pathogen relationship between Glycine max and Phakopsora pachyrhizi, the cause of soybean rust. Phytopathology, 66: $1290-1294$.

BoRland, J., and C. W. Mims. 1980. An ultrastructural comparison of the aecial and telial haustoria of the autoecious rust Puccinia podophylli. Mycologia, 72: 767-774.

Buller, A. H. R. 1950. Researches on fungi. Vol. VII. University of Toronto Press, Toronto.

COTTER, R. V. 1932. Factors affecting the development of the aecial stage of Puccinia graminis. U.S. Dep. Agric. Tech. Bull. 314: $1-20$

Cummins, G. B. 1978. Rust fungi: on legumes and composites in North America. University of Arizona Press, Tucson.

DEBARY, A. 1863. Recherches sur le développement de quelques champignons parasites. Ann. Sci. Nat. Bot. Biol, Veg. 20: 5-I48.

DinER, A. M., and R. L. MoTT. 1982. Axenic cultures from basidiospores of Cronartium ribicola. Can. J. Bot. 60: 1950- 1955.

ERIKSSON, J. 1911. Der Malvenrost. K. Sven. Vetenskapsakad. Handl. 47: $1-125$.

FISCHER, ED. 1898. Entwicklungsgeschichtliche Untersuchungen über Rostpilze. Beitr. Kryptogamenflora Schweiz, 1: 1-121.

GOLD, R. E. I983. Activation and pattern of teliospore germination in Uromyces appendiculatus var, appendiculatus and basidiospore infection of Phaseolus vulgaris. Doctoral dissertation, Universität Konstanz, Konstanz, Federal Republic of Germany

GOLD, R. E., and L. J. LITTLEFIELD. 1979. Light and scanning electron microscopy of the telial, pycnial, and aecial stages of Melampsora lini. Can. J. Bot. 57: 629-638.

Gold, R. E., and K. MEndGen. 1983a. Activation of teliospore germination in Uromyces appendiculatus var. appendiculatus. I. Aging and temperature. Phytopathol. Z. 108: 267-280.

$1983 b$. Activation of teliospore germination in Uromyces appendiculatus var. appendiculatus. II. Light and host volatiles. Phytopathol. Z. 108: 281-293.

1984. Vegetative development of Uromyces appendiculatus var. appendiculatus in Phaseolus vulgaris. Can. J. Bot. 62: This issue.

Gray, D. J., H. V. Amerson. and C. G. VAn Dyke. 1982. An ultrastructural comparison of monokaryotic and dikaryotic haustoria formed by the fusiform rust fungus Cronartium quercuum $\mathrm{f}$. sp. fusiforme. Can. J. Bot. 60: 2914-2922.

1983. Ultrastructure of the infection and early colonization of Pinus taeda by Cronartium quercuum formae speciales fusiforme. Mycologia, 75: 117-130.

GRILL, D., E. LACKNER, and M. SChARNER. 1978. Untersuchungen an mit Chrysomyxa abietis befallenen Fichtennadeln. Phyton, 19: $7 \mathrm{I}-82$

Hansen, E. M., and R. F. PAtTon. 1977. Factors important in artificial inoculation of Pinus strobus with Cronartium ribicola. Phytopathology, 67: 1108-1112.

HARDER, D. E., and J. CHONG. 1984. Structure and physiology of haustoria. In The cereal rusts. Vol. 1. Edited by W. R. Bushnell and A. P. Roelfs. Academic Press, New York. pp. 431-476.
Hardwick, N. V., A. D. Greenwood, and R. K. S. Wood. 1971. The fine structure of Uromyces appendiculatus in Phaseolus vulgaris. Can. J. Bot. 49: 383-390.

HunT, P. 1968. Cuticular penetration by germinating uredospores. Trans. Br. Mycol. Soc. 51: 103-112.

JACOBI, W. R., H. V. AMERSON, and R. L.MOTT, 1982. Microscopy of cultured loblolly pine seedlings and callus inoculated with Cronartium fusiforme. Phytopathology, 72: 138-143.

KANEKO, S., and N. HIRATSUKA. 1981. Blastospora betulae (Uredinales) from Japan. Mycologia, 73: 577-580.

KoHNO, M., H. IsHIZAKI, and H. KUNOH. 1976. Cytological studies on rust fungi. V. Intracellular hyphae of Gymnosporangium haraeanum Sydow in cells of Japanese pear leaves. Ann. Phytopathol. Soc. Jpn. 42: 417-423.

- 1977. Cytological studies on rust fungi. VI. Fine structures of infection process of Kuehneola japonica (Diet.) Dietel. Mycopathologia, 61: 35-41.

KOHNO, M., T. NiSHIMURA, H. ISHIZAKI, and H. KUNOH. 1975. Cytological studies on rust fungi. II. Ultrastructure of sporidia of Puccinia horiana P. Hennings. Bull. Fac. Agric. Mie Univ. 48: $9-15$.

Kohno, M., T. Nishimura, M. Noda, H. IshiZaKi, and H. KunOH. 1977. Cytological studies on rust fungi. VII. The nuclear behavior of Gymnosporangium asiaticum Miyabe et Yamada during the stages from teliospore germination through sporidium germination. Trans. Mycol. Soc. Jpn. 18: 211-219.

LAMB, I. M. 1935. The initiation of the dikaryophase in Puccinia phragmitis (Schum.) Korn. Ann. Bot. (London), 49: 403-438.

LANDES, M., and G. M. HOFFMAN. 1979. Zum Keimungsverlauf bei Colletotrichum lindemuthianum auf Phaseolus vulgaris. Phytopathol. Z. 95: 259-273.

LAPP, M. S., and W. P. SKOROPAD. 1978. Location of appressoria of Colletotrichum graminicola on natural and artificial barley leaf surfaces. Trans. Br. Mycol. Soc. 70: 225-228.

LINDFORS, TH. 1924. Studien über den Entwicklungsverlauf bei einigen Rostpilzen aus zytologischen und anatomischen Gesichtspunkten. Sven. Bot. Tidskr. 18: 1-84.

LiTTLEFIELD, L. J., and M. C. HEATH. 1979. Ultrastructure of rust fungi. Academic Press, New York.

Melander, L. W., and J. H. Craigie. 1927. Nature of resistance of Berberis spp. to Puccinia graminis. Phytopathology, 17: 95-114.

Melhus, I. E., L. W. Durrell, and R. S. KIrby. 1920. Relation of the barberry to stem rust in lowa. Iowa Agric. Exp. Stn. Res. Bull. 57: $283-325$.

MENDGEN, K. 1978. Der Infektionsverlauf von Uromyces phaseoli bei anfälligen und resistenten Bohnensorten. Phytopathol. Z. 93: 295-313.

Mercer, P. C., R. K. S. WoOd, and A. D. Greenwood. 1975. Ultrastructure of the parasitism of Phaseolus vulgaris by Colletotrichum lindemuthianum. Physiol. Plant Pathol. 5: 203-214.

METZLER, B. 1980. Ontogenie von Gymnosporangium fuscum DC. (Uredinales) in der Haplophase und damit verbundene Wirt-ParasitBeziehungen. Diplomarbeit, Universität Tübingen, Tübingen, Federal Republic of Germany

- 1982. Untersuchungen an Heterobasidiomyceten. 23. Basidiosporenkeimung und Infektionsvorgang beim Birnengitterrost. Phytopathol. Z. 103: 126-138.

Miller, T., R. F. Patton, and H. R. Powers, JR. 1980. Mode of infection and early colonization of slash pine seedlings by Cronartium quercuum f. sp. fusiforme. Phytopathology, 70: 1206- 1208 .

Mims, C. W. 1977. Fine structure of basidiospores of the cedar-apple rust fungus Gymnosporangium juniperi-virginianae. Can. J. Bot. 55: $1057-1063$.

- 1981. Ultrastructure of teliospore germination and basidiospore formation in the rust fungus Gymnosporangium clavipes. Can. J. Bot. 59: 1041-1049.

Nusbaum, C. J. 1935. A cytological study of the resistance of apple varieties to Gymnosporangium juniperi-virginianae. J. Agric. Res. 
51: $573-596$.

OLIVE, L. S. 1953. The structure and behavior of fungus nuclei. Bot. Rev. 19: 439-586.

PATTON, R. F., and D. W. Johnson. 1970. Mode of penetration of needles of eastern white pine by Cronartium ribicola. Phytopathology. 60: $977-982$.

PRING, R, J. 1980. A fine structural study of the infection of leaves of Phaseolus vulgaris by uredospores of Uromyces phaseoli. Physiol. Plant Pathol. 17: 269-276.

RÁTHAY, E. 1881. Über das Eindringen der Sporidienkeimschläuche der Puccinia malvacearum Mont. in die Epidermiszellen der Althaea rosea. Verh. Zool. Bot. Ges. Wien, 31: 9-10.

REED. H. S., and C. H. CRABILL. 1915. The cedar rust disease of apples caused by Gymnosporangium juniperi-virginianae Schw. Va. Agric. Exp. Stn. Tech. Bull. 9: 1-106.

REESS, M. 1870. Die Rostpilzformen der deutschen Coniferen. Abh. Naturf. Ges. Halle, 11: 50-118.

1874. Über eine an Puccinia malvacearum Mont. angestellte Untersuchung des Herrn stud. Ch. Kellermann. Sitzungsber. Phys. Med. Soc. Erlangen, 6: 157-160.

RIJKENBERG, F. H. J., G. T. N. DE LEEUW, and K. VerhoEFF. 1980. Light and electron microscopy studies on the infection of tomato fruits by Botrytis cinerea. Can. J. Bot. 58: 1394-1404.

RIJkEnBERG, F. H. J., and S. J. TRUTER. 1973. Haustoria and intracellular hyphae in the rusts. Phytopathology, 63: 281-286.

RoBb, J., A. E. HARVEY, and M. SHAW. 1975. Ultrastructure of tissue cultures of Pinus monticola infected by Cronartium ribicola. II. Penetration and post-penetration. Physiol. Plant Pathol. 5: 9-18.

RobInSON, W. 1913. XI. On some relations between Puccinia malvacearum (Mont.) and the tissues of its host plant (Althaea rosea). Manchester Mem. 57: 1-24.

SAto. T., K. KatsuYa, and S. Sato. 1980. Host range, teliospore germination and infection process of Uromyces aloes. Trans. Mycol. Soc. Jpn. 21: 273-282.

SNOw, G. A. 1968. Time required for infection of pine by Cronartium fusiforme and effect of field and laboratory exposure after inoculation. Phytopathology, 58: 1547-1550.

STAPLES, R. C., and V. MACKO. 1980. Formation of infection structures as a recognition response in fungi. Exp. Mycol. 4: 2-16.

ThirumalachaR, M. J. 1939. Rust on Jasmium grandiflorum. Phytopathology, 29: 783-792.

VAN ARSDEL, E. P. 1972. Environment in relation to white pine blister rust infection. In Biology of rust resistance in forest trees. Proc. NATO-IUFRO Adv. Study Inst. U.S. Dep. Agric. For. Serv. Misc. Publ. 1229. pp. 479-493.

WARD, M. H. 1888. Illustrations of the structure and life history of Puccinia graminis, the fungus causing the "rust" of wheat. Ann. Bot. (London), 2: 217-222.

WATERHOUSE, W. L. 1921. Studies in the physiology of parasitism. VII. Infection of Berberis vulgaris by sporidia of Puccinia graminis. Ann. Bot. (London), 35: 557-564.

WeIMER, J. L. 1917. Three cedar rust fungi. Their life histories and the diseases they produce. Cornell Univ. Agric. Exp. Stn. Bull. 390: $507-549$.

Wynn, W. K., and R. C. Staples. 1981. Tropisms of fungi in host recognition. In Plant disease control. Edited by R. C. Staples. John Wiley and Sons, New York. pp. 45-69. 